\title{
Cryopreservation of Hematopoietic Stem Cells: Emerging Science, Technology and Issues
}

\author{
Katie K. Fleming Allison Hubel \\ Department of Mechanical Engineering, University of Minnesota, Minneapolis, MN, USA
}

\section{Key Words}

Hematopoietic stem cells · Cryopreservation . Microfluidics · Storage

\section{Summary}

Cell therapies based on hematopoietic stem cells (HSCs) have become the standard of care for a variety of diseases, and the number of patients and disorders being treated using HSCs continues to grow. Effective methods of preservation are critical for the clinical implementation of HSC-based therapies. Preservation permits the completion of safety and quality control testing, transportation to the site of use and coordination of the therapy with patient care regimes. This review discusses advances in the basic science of preservation that will permit us to improve preservation protocols for HSCs and other cell types. Recent advances in preservation technology can also be used to reduce cell losses during cell processing for preservation and improve the safety of HSCs used therapeutically. Finally, the growth of HSC therapy worldwide has created interest in alternative methods of preservation. This review also includes a discussion of different methods of freezing and storage. Improved methods for preserving HSCs will improve not only therapies based on these cells but can improve and speed development of preservation protocols for other cell types used therapeutically.

\section{Schlüsselwörter}

Hämatopoetische Stammzellen · Kryokonservierung ·

Microfluidics · Lagerung

\section{Zusammenfassung}

Zelluläre Therapien mit hämatopoetischen Stammzellen (HSCs) sind zur Standardbehandlung für eine Vielzahl von Erkrankungen geworden. Die Anzahl der Patienten und Krankheiten, die mit HSCs behandelt werden, wächst. Effektive Konservierungsmethoden sind erforderlich für die Etablierung HSC-basierter Therapien in der Klinik. Das Haltbarmachen erlaubt auch die Vervollständigung der Sicherheits- und Qualitätstestung, den Transport an den Anwendungsort und die patientenbezogene Koordinierung der Therapie. Diese Übersichtsarbeit diskutiert die Fortschritte der zugrundeliegenden wissenschaftlichen Erkenntnisse, die es uns erlauben werden, die Konservierungsprotokolle für HSCs und andere Zellarten zu verbessern. Die neuesten technologischen Fortschritte bei der Konservierung können auch dafür genutzt werden, Zellverluste während der Prozessierung zu verringern und die therapeutische Sicherheit der HSCs zu verbessern. Die Zunahme HSC-basierter Therapien hat das Interesse an alternativen Methoden zur Haltbarmachung geweckt. Diese Übersichtsarbeit enthält deshalb auch eine Diskussion der verschiedenen Methoden des Einfrierens und der Lagerung. Verbesserte Konservierungsmethoden für HSCs werden nicht nur die Therapien verbessern, die auf diesen selbst basieren, sondern können auch dazu beitragen, Methoden der Haltbarmachung für andere therapeutisch genutzte Zellarten zu verbessern.

\begin{tabular}{ll}
\hline KARGER & @ 2007 S. Karger GmbH, Freiburg \\
$\begin{array}{l}\text { Fax }+497614520714 \\
\begin{array}{l}\text { E-mail Information@Karger.de } \\
\text { www.karger.com }\end{array}\end{array}$ & $\begin{array}{c}\text { Accessible online at: } \\
\text { www.karger.com/tmh }\end{array}$ \\
&
\end{tabular}

Allison Hubel, Ph.D.

Department of Mechanical Engineering, University of Minnesota

1100 Mechanical Engineering

111 Church Street SE, Minneapolis, MN 55455, USA

Tel +1 612-6264451, Fax -6254344

E-mail hube1001@umn.edu 


\section{Introduction}

Studies of the freezing response of hematopoietic stem cells (HSCs) has started in the mid 1950s, and cryopreservation of HSCs in conjunction with HSC transplantation has been commonly used for over 20 years [1-3]. The first studies focused on the freezing response of bone marrow [4]. Protocols for peripheral blood progenitor cells from drug-mobilized donors and umbilical cord blood were developed after the transplantation potential of these cells was determined [5-16].

The use of cells for therapeutic purposes is associated with specific challenges, preservation being one of them (table 1). The ability to preserve cells facilitates patient access to cellbased therapies as it permits transportation from the site of processing to the site of use. For HSC-based therapies, the ability to freeze cells increases the genetic diversity of patients that can be treated. The ability to preserve cells permits the development of a 'manufacturing' paradigm for cell therapy by facilitating inventory control and staffing. Finally, effective methods of preservation can improve the safety and quality of cell-based therapies by permitting time for completion of safety and quality control testing and increasing the shelf life of the product.

The purpose of this article is not a comprehensive review of historical studies of HSC freezing. Readers interested in a more comprehensive review of HSC preservation should read reviews by Sputtek and colleagues [17-20]. A more recent review also described studies regarding the influence of cell source, concentration and liquid storage prior to cryopreservation [21]. In this review, we will summarize emerging science, technology and issues in the HSC cryopreservation field. Specifically, we will discuss advances in our understanding of molecular level responses of HSCs to the stresses of freezing and thawing, advances in technology for preservation processing, and emerging issues in HSC preservation.

For some, cryopreservation of HSCs is a fait accompli. HSCs are cryopreserved, patients receive frozen and thawed cells many of which engraft and reconstitute hematopoiesis. Our ability to preserve the cells does not abrogate the need to improve the process. In a review of challenges to cell processing, Gee [22] stated: 'It is evident that both techniques adequately preserve the hematopoietic potential of cells, but it is not clear whether they are truly optimal'. Further work is needed to improve post-thaw viability and decrease adverse reactions from the infusion of cryopreserved HSCs. Improvements in HSC preservation has the potential to impact in a positive fashion not only the transplantation of this cell type but also other cell therapies. Our experiences with processing and transplantation of HSCs have created an important foundation for the use of hematopoietic and non-hematopoietic cells for therapeutic applications (e.g. lymphocytes, dendritic cells, mesenchymal stem cells) [23]. As the variety of cells, the number of patients, and the variety of disorders treated with cells increases, the need for safe and effective methods of cell preser- vation will only grow. Improvement in HSC preservation has the potential to improve and accelerate the development and preservation of cell therapies using other cell types.

\section{Emerging Science}

Our ability to detect and characterize progenitor/stem cells in hematopoietic cell products permits further studies into the freezing response of these cells. Over a decade ago, Zaheer and colleagues [24] documented a greater sensitivity of leukemic HSCs to freezing (versus HSC from normal donors). More recent studies have documented sensitivity of megakaryocyte progenitor cells from cord blood to freezing [25]. In contrast, Hubel and colleagues [23] observed an improvement in post-thaw recovery for frozen and thawed lymphocytes if they were cryopreserved 3 days after antigen stimulation. Whereas these studies do not suggest specific mechanism(s) for the sensitivity (or resistance) of these cell types, these studies underscore the need to understand the molecular basis for freeze sensitivity and cell-specific mechanisms of damage.

Studies examining the post-thaw behavior of HSCs points toward one potential location/subcellular site of freezing damage. Specifically, several investigators have studied the postthaw apoptosis of hematopoietic cells. The expression of apoptosis markers in HSCs both before and after freezing [26-28] has been observed. DeBoer and colleagues [26-27] noted that, if corrected for the fraction of cells expressing early stage apoptosis, the post-thaw viability of CD34+ cells was observed to decrease from $78 \%$ (measured with viability stains alone) to $42 \%$ (measured with apoptosis and viability stains combined). The authors further asserted that post-thaw apoptosis may influence the dose of CD34+ cells required for engraftment. The specific mechanism for post-thaw apoptosis was studied by Stroh and colleagues [29]. They observed that post-thaw apoptosis was mediated by the mitochondria and activated specifically by caspase 3 . Furthermore, they also observed that overexpression of BCL-2 and the use of caspase inhibitors protected the cells from post-thaw apoptosis. Postthaw apoptosis was also noted in other hematopoietic cells, specifically lymphocytes [30, 31]. As with the studies using HSCs, caspase inhibitors were observed to rescue cells from post-thaw apoptosis. The initiation and evolution of post-thaw apoptosis may in turn reflect other upstream events. Further work is needed to determine the location of injury and the sequence of events that results in cell losses for cells undergoing the stresses of freezing and thawing.

A variety of osmolytes including sugars are synthesized by organisms adapting to environmental stresses such as cold or desiccation [for review see 32]. Recent studies have demonstrated that one of those osmolytes, trehalose, improves postthaw viability when used with conventional cryopreservation protocols. Limaye et al. [33-35] demonstrated that catalase 
Table 1. Role of preservation in cell therapy.

\begin{tabular}{lll}
\hline Patient access & Manufacturability & Product safety and quality \\
\hline $\begin{array}{l}\text { Permits transportation to the site of use } \\
\text { (hospital, doctors office, clinic, battlefield). }\end{array}$ & $\begin{array}{l}\text { Permits coordination of therapy with patient } \\
\text { care regimes (cells are ready when patient is). }\end{array}$ & $\begin{array}{l}\text { Time for completion of safety and quality control } \\
\text { testing prior to product release. }\end{array}$ \\
Increases genetic diversity of cells available. & $\begin{array}{l}\text { Help management of staffing requirements at } \\
\text { cell processing facilities. }\end{array}$ & $\begin{array}{l}\text { Increased shelf life for product. } \\
\text { Permits inventory management of therapies. }\end{array}$ \\
& $\begin{array}{l}\text { Facilitates transportation between site of } \\
\text { collection and processing. }\end{array}$ \\
\hline
\end{tabular}

and trehalose were effective in the cryopreservation of HSCs. Scheinkönig and colleagues [36] found that the total number of colony-forming units was highest for cryopreservation solutions containing $0.5 \mathrm{~mol} / \mathrm{l}$ trehalose in $10 \%$ dimethyl sulfoxide (DMSO) solution. Zhang et al. [37] found similar results with umbilical cord blood. Buchanan and colleagues [38] studied the use of trehalose for the preservation of a HSC line. Low levels of trehalose $(0.2 \mathrm{~mol} / \mathrm{l})$ introduced into the cells using a genetically engineered membrane pore produced comparable levels of post-thaw colony formation to that observed for conventional DMSO-based solutions. Very low levels of postthaw viability measured with a fluorescent dye were observed in control studies (incubation of the cells in trehalose without the membrane pore) implying that trehalose has to be inside the cell to be effective. Other human cells such as fetal skin cells [39], oocytes [40, 41], pancreatic islets [42], platelets [43, 44], and red blood cells [45] have been frozen in solutions containing trehalose with improved outcome. Most mammalian cells do not synthesize trehalose, and it is not actively transported across the cell membrane, at least not in concentrations needed for preservation $(0.2-0.3 \mathrm{~mol} / \mathrm{l})$. As such, the transport of trehalose into the cells is a major technical hurdle for its use in cell preservation. Trehalose has been introduced into a cell using various methods: osmotic shock, thermotropic loading, microinjection, electroporation, and membrane disruption using sound waves [for review see 46]. Preservation of HSCs using sugars will require the development of methods for their introduction to a large number of cells $\left(10^{9}-10^{10}\right.$ cells) using clinically appropriate methods with minimal cell losses.

\section{Emerging Technology}

Advances in preservation science need to be supported by advances in preservation technology to improve the overall efficacy of the preservation process. New technologies to improve cell processing for preservation has the potential to benefit HSC-based therapies and other types of cell therapies under development.
Cryoprotectant (CPA) solutions are not physiological. For example, a 10\% DMSO solution is approximately 1.4 Osm (versus 270-300 mOsm for isotonic solutions). When transferred from an isotonic solution to a CPA solution containing DMSO, cells exhibit a rapid efflux of water as the cell attempts to reduce the difference in chemical potential between intracellular and extracellular solutions (fig. 1a). Slowly, the DMSO from the surrounding solution permeates the cell membrane. Both the rate of volume change and the absolute volume changes experienced by the cell can produce cell lysis [for review see 47]. Cells also experience volumetric excursions upon dilution or removal from a cryopreservation solution. Transfer of a cell equilibrated with a CPA solution into an isotonic solution will produce a rapid influx of water to decrease the chemical potential of the intracellular solution followed by a slow efflux of DMSO (fig. 1b). Cells are much more sensitive to lysis upon expansion (versus dehydration) so post-thaw removal protocols are critical for preventing cell losses. Current processing protocols for cord blood include a dilution step with a dextran/albumin solution in order to reduce osmotic stresses during washing of the cells [10].

Cell losses can result not only from introduction or removal of CPA solutions but also from exposure to the solution. Early studies demonstrated the sensitivity of HSCs to DMSO both pre freeze and post thaw [for review see 17]. Thus, processing protocols require that after DMSO is added to the cell suspension it be placed immediately into a controlled rate freezer or mechanical freezer to begin the freezing process. Although the sensitivity to DMSO was found to be less than previously thought [48], conventional wisdom still minimizes exposure to DMSO both pre freeze and post thaw. Thus, cryopreserved HSC suspensions are routinely thawed at the patient bedside and infused directly into the patient.

The direct infusion of cryopreserved HSC products has been associated with adverse reactions in patients. Less severe adverse reactions, including nausea, hypotension, dyspnea, chills and cardiac arrhythmia [48-51], are experienced by the majority of patients. Smaller numbers of patients experience more severe reactions, including cardiac arrest $[52,53]$, transient heart blockage [54], neurological toxicity [55], renal failure 
Fig. 1. Osmotic excursions when cells are $\mathbf{a}$ introduced into a CPA solution containing penetrating CPA; and $\mathbf{b}$ removed from a CPA solution containing penetrating CPA.

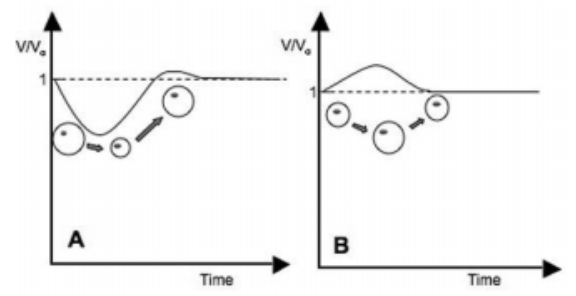

$[49,56]$, and respiratory arrest [57]. Studies on HSC transplants in children show that reactions in this patient group are more severe [58-60]. Several of these studies examined the relationship between transfusion reactions and DMSO content of the transplanted cells [54, 56, 61-63]. These studies noted that the greater the dose of DMSO, the more severe the adverse reaction or that removing DMSO reduced the incidence and severity of the transfusion reaction.

Protocols for transplantation of umbilical cord blood specify post-thaw washing of cells for the removal of DMSO [10]. Post-thaw washing of cord blood using centrifugation has been associated with significant losses. Losses of $27-30 \%$ of nucleated cells were observed by Antonenas and colleagues [61], with slightly lower losses observed in a subsequent study [64] using modified centrifugation technique to maximize cell recovery. Using an automated cell washer to remove DMSO from frozen and thawed cord blood resulted in similar losses [65].

Technologies have been developed for the removal of CPA solutions from frozen and thawed blood cells (not HSC products). Red blood cells are frozen using high-concentration glycerol solutions (17.5 or $40 \%$ ) requiring post-thaw washing to prevent extensive intravascular hemolysis upon re-infusion [66]. Valeri and colleagues $[67,68]$ have demonstrated the removal of glycerol using an automated cell washer (Haemonetics ACP-215) with good cell recovery. Arnaud and colleagues [69] have experimented with a hollow fiber membrane filtration system for DMSO removal from platelets suspensions. The device was successful at removing the DMSO present, and the cell losses were comparable to those after conventional cell washing using centrifugation. The automated cell washer and hollow fiber membrane filtration systems are designed specifically for the products used in those systems and cannot be directly applied to frozen and thawed HSC products. In addition, neither product improves the overall outcome when compared to centrifugation.

Microfluidics is one technology under investigation that could be used to improve preservation processing of cells. In this microfluidic device, diffusion-based extraction can be used to remove DMSO without centrifugation. This type of device has several advantages, including low power requirements, portability, and controllability of cell motion. Fleming and colleagues [70] modeled the diffusion-based transport in microfluidic channels to remove DMSO from a cell suspension.
Early studies have demonstrated the ability to remove DMSO with little cell loss [71]. Further studies are underway to determine the behavior of a clinical scale device capable of processing 2-3 $\mathrm{ml} / \mathrm{min}$ of cell suspension. A microfluidic device for post-thaw processing of cells to remove the CPA solution can be easily integrated into closed cell processing systems at the patient's bedside or in the cell processing laboratory. Introduction of CPA solutions also requires care, and this same type of device could be used to introduce a solution.

\section{Emerging Issues}

Controlled rate freezers are most commonly used to freeze HSC products followed by storage on liquid nitrogen $[1,2]$. This approach requires the purchase of a controlled rate freezer and liquid nitrogen storage units (with appropriate monitoring). In addition, infrastructure for delivery of liquid nitrogen to both the controlled rate freezer and storage units must be developed. As HSC transplantation and cell therapies based on HSCs spreads around the globe, there is considerable interest in development and validation of effective methods of freezing and storage of cells that does not require liquid nitrogen, in particular for locations in which liquid nitrogen may not be readily available.

The freezing and storage of HSCs are separate processes with the freezing process defined as processing of cells from the initial temperature (typically room temperature or $4{ }^{\circ} \mathrm{C}$ ) to a final storage temperature, and storage as the holding of a sample for a long period of time at a given constant low temperature. Evaluation of methods of freezing or storage centers on accurate, meaningful methods of post-thaw viability/functionality assessment. As such, we will also discuss some of the particular challenges associated with post-thaw assessment for HSCs.

\section{Freezing and/or Storage in Mechanical Freezers}

Early studies on cryopreservation of cells using a $-80{ }^{\circ} \mathrm{C}$ mechanical freezer (versus a controlled rate freezer) and a modified cryopreservation solution containing 5\% DMSO and 6\% hydroxyethyl starch (HES) were performed by Stiff and colleagues $[72,73]$. These studies established the feasibility of using uncontrolled freezing in a mechanical freezer with a modified solution. Katayama and colleagues [74] extended these studies by freezing peripheral blood stem cells (PBSCs) using a mechanical freezer followed by storage on $-80{ }^{\circ} \mathrm{C}$ for up to 5 years. Declines in viability (as determined by a fluorescent dye) were observed for cells stored on $-80{ }^{\circ} \mathrm{C}$, but colony formation did not show any significant declines. The influence of thawing temperature (i.e. warming rate) was also studied, and the use of higher $\left(37^{\circ} \mathrm{C}\right)$ temperatures was associated with increased post-thaw recovery. Halle and colleagues [75] cryopreserved PBSC products in a mechanical freezer using a modified cryopreservation solution composition $(3.5 \%$ 
DMSO and $2.5 \%$ HES). The post-thaw recovery for the cells frozen in a mechanical freezer were compared to that observed using controlled rate freezing and little difference in measures (CD34+, colony formation and cell counts) were observed. The cells were stored up to 6 months and thawed with comparable recovery. Many of the units that were cryopreserved were transplanted into patients, and the average time to engraftment was 11 days for patients infused with cells stored at $-80{ }^{\circ} \mathrm{C}$ for less than 6 months. The average number of days to engraftment increased to 12 days for cells stored at $-80^{\circ} \mathrm{C}$ for more than 6 months. Galmes and colleagues [76-78] cryopreserved PBSCs using a $-80{ }^{\circ} \mathrm{C}$ mechanical freezer and either 5 or $10 \%$ DMSO and observed little loss in colony forming capability of the cells for short term storage, but storage of more than 22 weeks resulted in a significant decline in colony forming capability. Almici and colleagues [79] studied the freezing of PBSC products in a 10\% DMSO solution using a mechanical freezer followed by storage on liquid nitrogen. In addition to studying the typical measures of post-thaw assessment, they measured the frequency of long-term culture-initiating cells (LTC-IC) both pre freeze and post thaw. The frequency of LTC-IC was not observed to vary with freezing. Sputtek and colleagues [80,81] demonstrated a decrease in the clonogenic potential of PBSCs as well as loss of membrane integrity for these same cells during storage of PBSC products at $-80{ }^{\circ} \mathrm{C}$. Fowke et al. [82] studied the influence of storage temperature on apoptosis expression in PBSC products. Samples stored at $-30^{\circ} \mathrm{C}$ exhibited significantly higher levels of apoptosis than those stored at -70 and $-150{ }^{\circ} \mathrm{C}$.

The studies described above use a wide array of experimental conditions (solution composition, storage conditions, product frozen, etc). Interpretation of the studies is also confounded by the fact that both freezing and storage was performed in $-80{ }^{\circ} \mathrm{C}$ mechanical freezers for most (but not all) studies. Thus, it is difficult to determine if declines in post-thaw viability result from freezing or storage or both. In interpreting these studies, certain basic biophysical principles should be considered. Cell suspensions contain two basic components: the CPA solution and cells. For typical CPA solutions used in conventional freezing methods, the CPA solution is not fully solidified until the sample is at or below the eutectic temperature [83]. For a solution containing 10\% DMSO, the eutectic temperature is approximately $-70{ }^{\circ} \mathrm{C}$. Storage of cells at or near those temperatures will imply that the CPA solution may not be fully solidified. Cells will still be surrounded by highly concentrated solutions and ice crystals can continue to grow and coalesce. The eutectic temperature of a solution is a function of solution composition [84]. Thus, it is not possible to translate the results of storage studies using one solution composition to another.

The biological activity of the cells is also influenced by temperature. Many cell functions are fully suppressed at temperatures $\leq 50{ }^{\circ} \mathrm{C}$ (water transport, metabolism) but enzymatic activity persists at much lower temperatures [85]. In the study by
Fowke and colleagues [82] described above, the expression of apoptosis markers measured in whole blood at various storage temperatures was determined. Much higher levels of expression of apoptosis markers were measured for whole blood stored at temperatures greater than $-150{ }^{\circ} \mathrm{C}$ but their studies using PBSC products did not observe the same difference. Thus, storage studies on one cell type cannot be directly translated to other cell types.

\section{Post-Thaw Assessment}

A major difficulty in determining the influence of freezing/ storage conditions on post-thaw recovery involves limitations with post-thaw viability assessment of HSCs. Sputtek and colleagues $[80,81,86]$ noted difficulties in obtaining accurate measures of post-thaw viability for HSC products. Total nucleated cell count, 'viability', CD34+ enumeration, and colony formation in methylcellullose (CFU) are the most commonly determined measures of post-thaw viability $[1,2]$. Each of these measures suffers from specific issues that make quantitative interpretation of the measure difficult. Specifically, quantification of $\mathrm{CFU}$ has been shown to be highly variable and influenced by operator/location. In a study by Burger and colleagues [87], colony formation in fresh (not frozen) HSCs demonstrated significant variability resulting from sample preparation. Thus comparison of the frequency of colony formation between locations or even different operators at the same location is difficult.

'Viability' of HSCs is traditionally determined using either trypan blue exclusion or fluorescent membrane integrity dyes [7]. Dyes that rely on membrane integrity as a measure of viability may (or may not) correlate with functional outcome for cells in culture. It has been known for decades that membrane integrity measures correlate poorly with post-thaw function for cells that have been frozen and thawed [for review see 88]. The freezing of cells results in significant dehydration of the cells and phase transitions in the cell membrane [for review see 89, 90]. As such, intact cells that have been frozen and thawed can exhibit transient changes in membrane permeability so the fraction of cells 'viable' using membrane integrity dyes can vary with time post thawing, and 'viability' may not correlate with more functional measures of outcome (colony formation, engraftment, etc).

Typically, enumeration of CD34+ cells (HSCs) has been performed using flow cytometry. Considerable work has been put into standardization of methods for enumerating CD34+ cell content of fresh, non-frozen cells using flow cytometry [91, 92]. Uniformity for CD34+ cell quantification across different platforms and institutions has not, however, been achieved, and a recent study delineated differences between instruments and protocols for CD34+ cell enumeration [93]. Quantifying CD34+ cell content in frozen and thawed HSC products is also challenging for some of the same reasons described above. For example, studies have reported CD34+ cell recovery of $>100 \%$ and as high as $200 \%[65,94]$. There is no evi- 
dence that the freezing process spurs proliferation of HSCs. High levels of post-thaw recovery of CD34+ cells suggest problems with flow cytometric quantification of CD34+ cell content. Further work is needed to determine if changes in the membrane structure resulting from freezing could result in an increase in the non-specific binding of the antibodies used for analysis. Changes in optical properties resulting from the freezing process (forward and side scatter) may require the use of different gating techniques. These studies will be important in making quantification of CD34+ cell content before and after freezing more accurate.

Post-thaw assessment is also complicated by the method of sample preparation. Almost all assays performed require centrifugation of the cells followed by further manipulation (staining with antibodies or membrane integrity dyes, plating into culture media). The steps involved in the assays can result in a measurement bias. Typically, the frequency of a target cell (viable cell, CD34+ cell or colony forming cell) is determined for the population of intact cells before freezing. A similar measurement is made post thawing where the frequency of the target cell is determined as a function of intact cells post thawing. The basic problem is that the two populations studied (pre-freeze and post-thaw) are different. Specifically, the population of intact cells is less than the pre-freeze population because a significant fraction of cells have been lysed by the stresses of freezing and thawing. Thus, calculating the recovery of cells by dividing the frequency of target cells post thawing by the frequency of target cells before freezing biases the measurement because the fraction of cells lost during freezing (including target cells) is not included in the calculation. There are several methods of correction for this measurement bias. For example, the total number of target cells can be calculated before and after freezing (versus the frequency). This method should permit correction for the cells lost during the freezing process. Many of the studies discussed previously in this review reported $\sim 100 \%$ recovery in CD34+ cell content or CFU post thawing. It is unclear if the high levels of post-thaw recovery reported in various studies reflect actual post-thaw recovery or a systematic measurement bias.

\section{Conclusion}

Much of the preservation practice at the present time could be described as 'empirical cryopreservation' in which protocols are developed by varying solution composition and cooling rate to determine the 'optimal' protocol for cell preservation. This approach does little to determine specific mechanisms of damage and to facilitate the development of rational approaches to cell preservation. Recent advances in molecular biology and adaptation of organisms to stress are permitting us to gain insight into the molecular level mechanisms of damage and to develop methods of stabilizing cells [for review see 32]. Further work is needed to identify subcellular sites of damage and methods of stabilizing those structures against the stresses of freezing and thawing. The development of the next generation of cryoprotective agents is needed and will require rational methods of designing or screening of molecules with protective properties. This work will permit us to advance the science of preservation and provide the foundation for transforming cell preservation for HSCs and other cell types.

Effective methods of preservation also required development of the supporting relevant technology. Preservation technology has changed little since the 1950s. Current technologies such as microfluidics can be adapted to the cell preservation process to improve the introduction and removal of the specialized solutions used in cell preservation and thereby improves the overall safety and efficacy of the process. Further technology development is needed. Specifically, knowledge of the temperature history of each vial/bag during freezing and during storage is important for process monitoring and quality control. The basic technology for temperature monitoring of each unit exists but has not been adapted to cell preservation. The preservation process is only as good as the container that contains the product. Containers that do not fail at liquid nitrogen temperatures and permit sterile introduction and removal of cells have been developed but need to be expanded to provide a full range volumes used in cell preservation and integrate easily into inventory control systems to facilitate product retrieval from a repository.

The spreading of HSC-based therapies around the globe has led to interest in different methods of preserving cells for clinical use. Further work is needed to develop a 'menu' of methods that can be used to effectively preserve HSCs by methods appropriate for the clinical cell processing laboratory. The development and validation of these methods is, however, hampered by limitations in the assay of post-thaw viability. Cells that have been subjected to the stresses of freezing and thawing do not respond in the same manner to assays as fresh, nonfrozen cells. Much has been done to standardize assays performed on fresh products, and those efforts need to be extended to frozen and thawed products. The development of more representative post-thaw viability assays will benefit existing cell preservation processes as well as the development and validation of new processes. 


\section{References}

1 Areman EM, Sacher RA, Deeg HJ: Processing and storage of human bone marrow: a survey of current practices in North America. Bone Marrow Transplant 1990;6:203-209.

2 Areman EM, Sacher RA, Deeg HJ: Cryopreservation and storage of human bone marrow: a survey of current practices. Prog Clin Biol Res 1990;333: 523-529.

3 Barnes D, Loutit J: The radiation recovery factor: preservation by the Polge-Smith-Parkes technique. J Natl Cancer Inst 1955;15:901-905.

$\checkmark 4$ Appelbaum FR, Herzig GP, Graw RG, Bull MI, Bowles C, Gorin NC, Deisseroth AB: Study of cell dose and storage time on engraftment of cryopreserved autologous bone marrow in a canine model. Transplantation 1978;26:245-248.

$\checkmark 5$ Rowley SD: Hematopoietic stem cell processing and cryopreservation. J Clin Apheresis 1992;7: 132-134.

6 Rowley SD, Bensinger WI, Gooley TA, Buckner $\mathrm{CD}$ : Effect of cell concentration on bone marrow and peripheral blood stem cell cryopreservation. Blood 1994;83:2731-2736.

7 Fraser JK, Cairo MS, Wagner EL, McCurdy PR, Baxter-Lowe LA, Carter SL, Kernan NA, Lill MC, Slone V, Wagner JE, Wallas CH, Kurtzberg J: Cord Blood Transplantation Study (COBLT): cord blood bank standard operating procedures. J Hematother 1998;7:521-561.

8 M-Reboredo N, Diaz A, Castro A, Villaescusa RG: Collection, processing and cryopreservation of umbilical cord blood for unrelated transplantation. Bone Marrow Transplant 2000;26:1263-1270.

$\checkmark 9$ Shlebak AA, Marley SB, Roberts IA, Davidson RJ, Goldman JM, Gordon MY: Optimal timing for processing and cryopreservation of umbilical cord haematopoietic stem cells for clinical transplantation. Bone Marrow Transplant 1999;23:131-136.

10 Rubinstein P, Dobrila L, Rosenfield RE, Adamson JW, Migliaccio G, Migliaccio AR, Taylor PE, Stevens CE: Processing and cryopreservation of placental/umbilical cord blood for unrelated bone marrow reconstitution. Proc Natl Acad Sci U S A 1995;92:10119-10122.

11 Laughlin MJ, Barker J, Bambach B, Koc ON, Rizzieri DA, Wagner JE, Gerson SL, Lazarus HM, Cairo M, Stevens CE, Rubinstein P, Kurtzberg J Hematopoietic engraftment and survival in adult recipients of umbilical- cord blood from unrelated donors. N Engl J Med 2001;344:1815-1822.

12 Campos L, Roubi N, Guyotat D: Definition of optimal conditions for collection and cryopreservation of umbilical cord hematopoietic cells. Cryobiology 1995;32:511-515.

13 Hubel A, Carlquist D, Clay M, McCullough J: Short term liquid storage of umbilical cord blood. Transfusion 2003;43:626-632.

14 Hubel A, Carlquist D, Clay M, McCullough J: Cryopreservation of cord blood after liquid storage. Cytotherapy 2003;5:370-376.

15 Hubel A, Carlquist D, Clay M, McCullough J: Liquid storage, shipment, and cryopreservation of cord blood. Transfusion 2004;44:518-525.

16 Chrysler G, McKenna D, Schierman T, Kadidlo D, Askari S, Miller J, Clay M, McCullough J: Umbilical cord blood banking; in Broxmeyer HE (ed) Cellular Characteristics of Cord Blood and Cord Blood Transplantation. Bethesda, AABB Press, 2004, pp 219-257.

17 Sputtek A: Cryopreservation of red blood cells, platelets, lymphocytes, and stem cells. in Fuller B, Grout B (eds): Clinical Applications of Cryobiology. Boca Raton, CRC Press, 1991, pp 95-147.
18 Sputtek A: Kryokonservierung von Blutzellen und hamatoppoetischen Stammzellen; in Müller-Eck hart C, Kiefel V (Hrsg): Transfusionsmedizin. Berlin, Springer, 2004.

19 Sputtek A, Gutensohn K, Hummel K, Loliger C, Kühnl P: Zur Kryokonsevierung von Blutstammzellen. J Lab Med 1996;20:70-77.

20 Sputtek A, Sputtek R: Cryopreservation in transfusion medicine and hematology; in Fuller BJ, Lane N, Benson E (eds): Life in the Frozen State. Boca Raton, CRC Press, 2004, pp 483-504.

21 Fleming KK, Hubel A: Cryopreservation of hemato-poietic and non-hematopoietic stem cells. Transfus Apher Sci 2006;34:309-315.

22 Gee AP: Challenges in autologous graft manipulation; in Dickie K, Keating A (eds): Autologous Blood and Marrow Transplantation. Charlottesville, CJP, 2001, vol X, pp 19-29.

23 Hubel A: Cellular preservation - gene therapy, cellular metabolic engineering; in Baust JG (ed): Advances in Biopreservation. Boca Raton, CRC Press, 2006, pp 143-156.

24 Zaheer HA, Gibson FM, Bagnara M, GordonSmith EC, Rutherford TR: Differential sensitivity to cryopreservation of clonogenic progenitor cells and stromal precursors from leukemic and normal bone marrow. Stem Cells 1994;12:180-186.

25 Xu Y, Kashiwakura I, Takahashi TA: High sensitivity of megakaryocytic progenitor cells contained in placental/umbilical cord blood to the stresses during cryopreservation. Bone Marrow Transplant 2004;34:537-543

26 de Boer F, Drager AM, Pinedo HM, Kessler FL, Monnee-van Muijen M, Weijers G, Westra G, van der Wall E, Netelenbos T, Oberink JW, Huijgens PC, Schuurhuis GJ: Early apoptosis largely accounts for functional impairment of CD34+ cells in frozen-thawed stem cell grafts. J Hematother Stem Cell Res 2002;11:951-963.

27 de Boer F, Drager AM, Pinedo HM, Kessler FL, van der Wall E, Jonkhoff AR, van der Lelie J, Huijgens PC, Ossenkoppele GJ, Schuurhuis GJ: Extensive early apoptosis in frozen-thawed CD34-positive stem cells decreases threshold doses for haematological recovery after autologous peripher al blood progenitor cell transplantation. Bone Marrow Transplant 2002;29:249-255.

28 Greco NJ, Seetharaman S, Kurtz J, Lee WR, Moroff G: Evaluation of the reactivity of apoptosis markers before and after cryopreservation in cord blood CD34(+) cells. Stem Cells Dev 2006;15: 124-135.

29 Stroh C, Cassens U, Samraj AK, Sibrowski W, Schulze-Osthoff K, Los M: The role of caspases in cryoinjury: caspase inhibition strongly improves the recovery of cryopreserved hematopoietic and othe cells. Faseb J 2002;16:1651-1653.

30 Sarkar S, Kalia V, Montelaro RC: Caspase-mediated apoptosis and cell death of rhesus macaque CD4+ T-cells due to cryopreservation of periphera blood mononuclear cells can be rescued by cytokine treatment after thawing. Cryobiology 2003; 47:44-58.

31 Stroncek DF, Hubel A, Shankar RA, Burger SR, Pan D, McCullough J, Whitley CB: Retroviral transduction and expansion of peripheral blood lymphocytes for the treatment of mucopolysaccharidosis type II, Hunter's syndrome. Transfusion 1999;39:343-350.

32 Aksan A, Toner M: Roles of thermodynamic state and molecular mobility in biopreservation; in Bronzino JD (ed): Tissue Engineering and Artificial Organs. Boca Raton, Taylor and Francis, 2006, pp 1-20.
3 Limaye LS, Kale VP: Cryopreservation of human hematopoietic cells with membrane stabilizers and bioantioxidants as additives in the conventional freezing medium. J Hematother Stem Cell Res 2001;10:709-718.

34 Sasnoor LM, Kale VP, Limaye LS: Supplementation of conventional freezing medium with a combination of catalase and trehalose results in better protection of surface molecules and functionality of hematopoietic cells. J Hematother Stem Cell Res 2003;12:553-564.

35 Sasnoor LM, Kale VP, Limaye LS: A combination of catalase and trehalose as additives to conventional freezing medium results in improved cryoprotection of human hematopoietic cells with reference to in vitro migration and adhesion properties. Transfusion 2005;45:622-633.

36 Scheinkönig C, Kappicht S, Kolb HJ, Schleuning M: Adoption of long-term cultures to evaluate the cryoprotective potential of trehalose for freezing hematopoietic stem cells. Bone Marrow Transplant 2004;34:531-536.

37 Zhang XB, Li K, Yau KH, Tsang KS, Fok TF, Li CK, Lee SM, Yuen PM: Trehalose ameliorates the cryopreservation of cord blood in a preclinical system and increases the recovery of CFUs, long-term culture-initiating cells, and nonobese diabeticSCID repopulating cells. Transfusion 2003;43 265-272.

38 Buchanan SS, Gross SA, Acker JP, Toner M, Carpenter JF, Pyatt DW: Cryopreservation of stem cells using trehalose: evaluation of the method using a human hematopoietic cell line. Stem Cells Dev 2004;13:295-305.

39 Erdag G, Eroglu A, Morgan J, Toner M: Cryopreservation of fetal skin is improved by extracellular trehalose. Cryobiology 2002;44:218-228.

40 Eroglu A, Lawitts JA, Toner M, Toth TL: Quantitative microinjection of trehalose into mouse oocytes and zygotes, and its effect on development. Cryobiology 2003;46:121-134.

41 Wright DL, Eroglu A, Toner M, Toth TL: Use of sugars in cryopreserving human oocytes. Reprod Biomed Online 2004:9:179-186.

42 Beattie GM, Crowe JH, Lopez AD, Cirulli V, Ricordi C, Hayek A: Trehalose: a cryoprotectant that enhances recovery and preserves function of human pancreatic islets after long-term storage. Diabetes 1997:46:519-523.

43 Wolkers W, Walker N, Tablin F, Crowe JH: Human platelets loaded with trehalose survive freeze-drying. Cryobiology 2000;42:79-87.

44 Wolkers WF, Tablin F, Crowe JH: From anhydrobiosis to freeze-drying of eukaryotic cells. Comp Biochem Physiol A Mol Integr Physiol 2002;131: 535-543.

45 Satipathy G, Torok Z, Bali R, Dwyre D, Little E, Walker N, Tablin F, Crowe JH, Tsvetkova N: Loading red blood cells with trehalose: a step towards biostabilization. Cyobiology 2004;49:123-136.

46 Acker JP: The use of intracellular protectants in cell biopreservation. in Baust JG, Baust JM (eds): Advances in Biopreservation. Boca Raton, CRC Press, 2006, pp 299-320.

47 Fahy GM, Lilley TH, Linsdell H, Douglas MS Meryman HT: Cryoprotectant toxicity and cryoprotectant toxicity reduction: in search of molecular mechanisms. Cryobiology 1990;27:247-268.

48 Rowley SD, Anderson GL: Effect of DMSO exposure without cryopreservation on hematopoietic progenitor cells. Bone Marrow Transplant 1993;11: 389-393. 
49 Alessandrino P, Bernasconi P, Caldera D, Colombo A, Bonfichi M, Malcovati L, Klersy C, Martinelli G, Maiocchi M, Pagnucco G, Varettoni M, Perotti $\mathrm{C}$, Bernasconi C: Adverse events occurring during bone marrow or peripheral blood progenitor cell infusion: analysis of 126 cases. Bone Marrow Transplant 1999;23:533-537.

50 Davis J, Rowley SD, Santos GW: Toxicity of autologous bone marrow graft infusion. Prog Clin Biol Res 1990;333:531-540.

51 Stroncek DF, Fautsch SK, Lasky LC, Hurd DD, Ramsay NK, McCullough J: Adverse reactions in patients transfused with cryopreserved marrow. Transfusion 1991;31:521-526.

52 Berenson RJ, Shpall EJ, Auditore-Hargreaves K, Heimfeld S, Jacobs C, Krieger MS: Transplantation of CD34+ hematopoietic progenitor cells. Cancer Invest 1996;14:589-596.

-53 Zenhausern R, Tobler A, Leoncini L, Hess OM, Ferrari P: Fatal cardiac arrhythmia after infusion of dimethyl sulfoxide-cryopreserved hematopoietic stem cells in a patient with severe primary cardiac amyloidosis and end-stage renal failure. Ann Hematol 2000;79:523-526.

-54 Martino M, Morabito F, Messina G, Irrera G, Pucci G, Iacopino P: Fractionated infusions of cryopreserved stem cells may prevent DMSO-induced major cardiac complications in graft recipients. Haematologica 1996;81:59-61.

55 Hoyt R, Szer J, Grigg A: Neurological events associated with the infusion of cryopreserved bone marrow and/or peripheral blood progenitor cells. Bone Marrow Transplant 2000;25:1285-1287.

-56 Smith DM, Weisenburger DD, Bierman P, Kessinger A, Vaughan WP, Armitage JO: Acute renal failure associated with autologous bone marrow transplantation. Bone Marrow Transplant 1987;2:195-201.

57 Benekli M, Anderson B, Wentling D, Bernstein S, Czuczman M, McCarthy P: Severe respiratory depression after dimethylsulphoxide-containing autologous stem cell infusion in a patient with $\mathrm{AL}$ amyloidosis. Bone Marrow Transplant 2000;25: 1299-1301.

58 Garaventa A, Porta F, Rondelli R, Dini G, Meloni G, Bonetti F, Uderzo C, De Manzini A, Miniero R, Brutti F, et al: Early deaths in children after BMT. Bone Marrow Transplantation Group of the Italian Association for Pediatric Hematology and Oncology (AIEOP) and Gruppo Italiano Trapianto di Midollo Osseo (GITMO). Bone Marrow Transplant 1992;10:419-423.

59 Okamoto Y, Takaue Y, Saito S, Shimizu T, Suzue T, Abe T, Sato J, Hirao A, Watanabe T, Kawano Y, et al: Toxicities associated with cryopreserved and thawed peripheral blood stem cell autografts in children with active cancer. Transfusion 1993;33 578-581.

60 Thome S, Craze J, Mitchell C: Dimethylsulphoxideinduced serum hyperosmolality after cryopreserved stem-cell graft. Lancet 1994;344:1431-1432.

61 Antonenas V, Bradstock K, Shaw P: Effect of washing proceedures on unrelated cord blood units for transplantation in children and adults. Cytotherapy 2002;4:16.

62 Syme R, Bewick M, Stewart D, Porter K, Chadderton T, Gluck S: The role of depletion of dimethyl sulfoxide before autografting: on hematologic recovery, side effects, and toxicity. Biol Blood Marrow Transplant 2004;10:135-141.

63 Zambelli A, Poggi G, Da Prada G, Pedrazzoli P, Cuomo A, Miotti D, Perotti C, Preti P, Robustelli della Cuna G: Clinical toxicity of cryopreserved circulating progenitor cells infusion. Anticancer Res 1998;18:4705-4708.
64 Laroche V, McKenna DH, Moroff G, Schierman T, Kadidlo D, McCullough J: Cell loss and recovery in umbilical cord blood processing: a comparison of postthaw and postwash samples. Transfusion 2005; 45:1909-1916.

65 Perotti CG, Fante CD, Viarengo G, Papa P, Rocchi L, Bergamaschi P, Bellotti L, Marchesi A, Salvaneschi L: A new automated cell washer device for thawed cord blood units. Transfusion 2004;44: 900-906.

66 Valeri CR: The in vivo survival, mode of removal of the non-viable cells, and the total amount of supernatant hemoglobin in deglycerolized, resuspended erythrocytes. I. The effect of the period of storage in ACD at $4 \mathrm{C}$ prior to glycerolization. II. The effect of washing deglycerolized, resuspended erythrocytes after a period of storage at 4C. Transfusion 1965;5:273-285.

67 Valeri CR, Pivacek LE, Cassidy GP, Ragno G: Posttransfusion survival (24-hour) and hemolysis of previously frozen, deglycerolized RBCs after storage at 4 degrees $\mathrm{C}$ for up to 14 days in sodium chloride alone or sodium chloride supplemented with additive solutions. Transfusion 2000;40:1337-1340.

68 Valeri CR, Pivacek LE, Cassidy GP, Ragno G: 24hour 51Cr post-transfusion survival, 51Cr life span and haemolysis of red blood cells stored at 4 degrees C for 56 days in AS-3. Vox Sang 2001;80: $48-50$.

69 Arnaud F: Use of hollow fiber membrane filtration for the removal of DMSO from platelet concentrates. Platelets 2003;14:131-137.

70 Fleming KK, Longmire EA, Hubel A: Numerical characterization of diffusion-based extraction in cell-laden flow through a microfluidic channel. J Biomech Engr 2007; (in press).

71 Mata C, Longmire EA, Fleming KK, Hubel A: Experimental Study of Diffusion-Based Extraction from a Cell Suspension; in BMES Annual Meeting. Chicago, IL, BMES, 2006.

72 Stiff PJ, Koester AR, Weidner MK, Dvorak K, Fisher RI: Autologous bone marrow transplantation using unfractionated cells cryopreserved in dimethylsulfoxide and hydroxyethyl starch without controlled-rate freezing. Blood 1987;70:974-978.

73 Stiff PJ, Murgo AJ, Zaroulis CG, DeRisi MF, Clarkson BD: Unfractionated human marrow cell cryopreservation using dimethylsulfoxide and hydroxyethyl starch. Cryobiology 1983;20:17-24.

74 Katayama Y, Yano T, Bessho A, Deguchi S, Sunami K, Mahmut N, Shinagawa K, Omoto E, Makino S, Miyamoto T, Mizuno S, Fukuda T, Eto T, Fujisaki T, Ohno Y, Inaba S, Niho Y, Harada M: The effects of a simplified method for cryopreservation and thawing procedures on peripheral blood stem cells. Bone Marrow Transplant 1997;19:283-287.

75 Halle P, Tournilhac O, Knopinska-Posluzny W, Kanold J, Gembara P, Boiret N, Prapatel C, Berger M, Travade M, Angeilski S, Bonhomme J, Demeocq F: Uncontrolled-rate freezing and storage at -80 decrees C, with only 3.5-percent DMSO in cryoprotective solution for 109 autologous peripheral blood progenitor cell transplantations. Transfusion 2001;41:467-473.

76 Galmes A, Besalduch J, Bargay J, Matamoros N, Duran MA, Morey M, Alvarez F, Mascaro M: Cryopreservation of hematopoietic progenitor cells with 5-percent dimethyl sulfoxide at -80 degrees $\mathrm{C}$ without rate-controlled freezing. Transfusion 1996; 36:794-797.

77 Galmes A, Besalduch J, Bargay J, Matamoros N, Morey M, Novo A, Sampol A: A simplified method for cryopreservation of hematopoietic stem cells with -80 degrees $\mathrm{C}$ mechanical freezer with dimethyl sulfoxide as the sole cryoprotectant. Leuk Lymphoma 1995;17:181-184.
78 Galmes A, Besalduch J, Bargay J, Novo A, Morey M, Guerra JM, Duran MA: Long-term storage at -80 degrees $\mathrm{C}$ of hematopoietic progenitor cells with 5-percent dimethyl sulfoxide as the sole cryoprotectant. Transfusion 1999;39:70-73.

79 Almici C, Ferremi P, Lanfranchi A, Ferrari E, Ver ardi R, Marini M, Rossi G: Uncontrolled-rate freezing of peripheral blood progenitor cells allows successful engraftment by sparing primitive and committed hematopoietic progenitors. Haematologica 2003;88:1390-1395.

80 Sputtek A, Nowicki B, Rowe AW, Kühnl P: Longterm cryopreservation of human peripheral blood progenitor cells (PBPC): influence of storage temperature $\left(-80{ }^{\circ} \mathrm{C}\right.$ vs. $\left.\leq 170{ }^{\circ} \mathrm{C}\right)$ on cell recovery, membrane integrity, and clonogenicity. Cryobiology 2004;49:314.

81 Sputtek A, Rowe AW, Kühnl P: Long-term storage of peripheral blood progenitor cells at $-80 \mathrm{oC}$ leads to a pronounced decrease of the clonogenic potential compared to $£ 170^{\circ} \mathrm{C}$ storage in the vapor phase over liquid nitrogen. Cryobiology 2005;51:355.

82 Fowke KR, Behnke J, Hanson C, Shea K, Cosentino LM: Apoptosis: a method for evaluating the cryopreservation of whole blood and peripheral blood mononuclear cells. J Immunol Methods 2000;244: 139-144.

83 Cocks FH, Brower W: Phase diagram relationship in cryobiology. Cryobiology 1974;11:340-358.

84 Pegg DE: Equations for obtaining melting points and eutectic temperatures for three ternary system dimethyl sulphoxide/sodium chloride/water. CryoLetters 1986;7.

85 Tappel A: Effects of low temperature and freezing on enzymes and enzyme systems; in Meryman HT (ed): Cryobiology. New York, Academic Press, 1966, pp 163-177.

86 Sputtek A, Benndorf C, Rowe AW, Kühnl P: Postthaw storage of frozen peripheral blood stem cells decreases the hematopoietic potential. Cryobiology 2002;45:248-249.

87 Burger SR, Kadidlo D, McCullough J: Improved progenitor assay standardization using periphera blood progenitor cells from a donor treated with granulocyte-colony stimulating factor. Tranfusion 1999;39:451-456.

88 Pegg DE: Viability assays for preserved cells, tissues, and organs. Cryobiology 1989;26:212-231.

89 Mazur P: Principles of cryobiology; in Fuller BJ, Lane N, Benson E (eds): Life in the Frozen State. Boca Raton, CRC Press, 2004, pp 3-66.

90 Taylor MJ: Biology of cell survival in the cold: the basis for biopreservation of tissues and organs; in Baust JG, Baust JM (eds): Advances in Biopreservation. Boca Raton, CRC Press, 2006, pp 15-62.

91 Keeney M, Barnett D, Gratama JW: Impact of standardization on clinical cell analysis by flow cytometry. J Biol Regul Homeost Agents 2004;18: 305-312.

92 Keeney M, Gratama JW, Sutherland DR: Critical role of flow cytometry in evaluating peripheral blood hematopoietic stem cell grafts. Cytometry A 2004;58:72-75.

93 Rivadeneyra-Espinoza L, Perez-Romano B, Gonzalez-Flores A, Guzman-Garcia MO, CarvajalArmora F, Ruiz-Arguelles A: Instrument- and protocol-dependent variation in the enumeration of CD34+ cells by flow cytometry. Transfusion 2006; 46:530-536.

94 Itoh T, Minegishi M, Fushimi J, Takahashi H, Kudo Y, Suzuki A, Narita A, Sato Y, Akagi K, Wada Y, Saito A, Kikuchi M, Okamura K, Kaku M, Tsuchiya S: A simple controlled-rate freezing method without a rate-controlled programmed freezer provides optimal conditions for both largescale and small-scale cryopreservation of umbilica cord blood cells. Transfusion 2003;43:1303-1308. 